\title{
Ni-Fe ALLOY THIN FILMS FOR AMR SENSORS
}

\section{TANKE PLASTI ZLITINE Ni-Fe ZA IZDELAVO AMR-SENZORJEV}

\author{
Marijan Maček ${ }^{1}$, Alen Oblak ${ }^{2}$ \\ ${ }^{1}$ University of Ljubljana, Faculty of Electrical Engineering, Tržaška 25, 1000 Ljubljana, Slovenia \\ ${ }^{2}$ LEK, Verovškova 57, 1000 Ljubljana, Slovenia \\ marijan.macek@fe.uni-lj.si \\ Prejem rokopisa - received: 2016-07-15; sprejem za objavo - accepted for publication: 2016-09-19
}

doi:10.17222/mit.2016.203

\begin{abstract}
$\mathrm{Ni}$-Fe alloy films deposited in sputtering apparatus and the subsequent AMR sensor fabrication were successfully developed The results on test devices are comparable to the commercially available device with AMR as measured on the standard multipole magnetic tape.

Keywords: Ni-Fe alloy, AMR, sputtering
\end{abstract}

Razvit je bil postopek naprševanja in kasnejše obdelave tankih plasti zlitine Ni-Fe, potrebnih za izdelavo senzorjev AMR Rezultati testnih uporov, merjenih na standardnem, mnogopolnem magnetnem traku, so primerljivi s komercialnimi senzorji.

Ključne besede: zlitina Ni-Fe, AMR, naprševanje

\section{INTRODUCTION}

Magnetoresistance (MR) is a phenomenon that reflects the effect of an external magnetic field on the resistance change of certain materials. Among known MR the anisotropic magnetoresistance phenomenon (AMR) is widely used in the field of position sensors and encoders due to its robustness compared to optical ones. The AMR effect arises from spin-orbital coupling and therefore depends on the angle $\theta$ between the magnetic moment $M$ and the current $j .{ }^{1}$ Therefore, resistivity $\rho$ is a function of $\theta$ and can be written as in Equation (1), where the symbols $\perp$ and I denote the perpendicular and parallel components:

$$
\rho=\rho \| \sin ^{2} \theta+\rho \perp \cos ^{2} \theta
$$

The response, i.e., the difference between both components of resistivity, of AMR sensors strongly depends on the soft ferromagnetic material properties. A very common choice are $\mathrm{Ni}_{x} \mathrm{Fe}_{1-x}$ alloys, known under commercial name Ni-Fe alloy with typical concentration $x$ close to 0.8 . The properties of thin layers however depend on the deposition parameters (pressure, temperature, deposition rate, applied magnetic field), subsequent annealing and of course on the layer thickness. Conditions should be set in such a way as to obtain a highly oriented crystalline structure. In the absence of an external field during the film's deposition the correct deposition condition leads usually to the (111) preferred orientation of film with the easy axis of magnetisation perpendicular to the surface. For other orientations of the easy axis, an external magnetic field of $5-15 \mathrm{kA} / \mathrm{m}$ during deposition or subsequent annealing is essential.
In our work we concentrate the efforts in order to sputter deposit thin films of $\mathrm{Ni}-\mathrm{Fe}$ from a $\mathrm{Ni}_{80} \mathrm{Fe}_{20}$ target without an external magnetic field. Therefore, we are limited in variation of deposition parameters (power $P$ and $\operatorname{Ar}$ pressure $p_{\mathrm{Ar}}$ ), which influence the deposition rate and the chemical constitution ${ }^{1}$ of the deposited films and on to the effects of subsequent annealing at temperatures from $150{ }^{\circ} \mathrm{C}$ to above $400{ }^{\circ} \mathrm{C}$ in forming gas $\left(10 \% \mathrm{H}_{2}\right.$ in $\mathrm{N}_{2}$ ).

\section{EXPERIMENTAL PART}

Thin Ni-Fe films were deposited onto 500-nm-thick thermally grown $\mathrm{SiO}_{2}$ on 100 -mm $\mathrm{Si}$ test wafers. The depositions were performed in Perkin Elmer Sputtering Model 2400 apparatus working at a base pressure below $1.3 \times 10^{-4} \mathrm{~Pa}$ from a $\mathrm{Ni}_{80} \mathrm{Fe}_{20}$ target. The pressure of the Ar during the sputtering was set to $1.1 \mathrm{~Pa}$ as first results suggest that higher pressures give unsatisfactory results. The Ni-Fe alloy films were usually deposited onto a buffer layer in order to promote preferential (111) crystallite orientation. A very common buffer is Ta, but $\left(\mathrm{Ni}_{0.81} \mathrm{Fe}_{0.19}\right)_{0.66} \mathrm{Cr}_{0.34}$ layer $^{2}$ gives better results. We tried to simulate the $\mathrm{NiFeCr}$ depositing thin layer of $\mathrm{Cr} / \mathrm{NiFe} / \mathrm{Cr}$ in the way to reach preferred ratio between $\mathrm{Cr}$ and $\mathrm{Ni}-\mathrm{Fe}$ alloy.

The resistors were defined by the so-called lift-off process since with standard positive PR process and subsequent etching in $\mathrm{Ni}$ etchant the minimum dimension could not be kept in the desired limits. For test resistors devices with two different geometries $L x W$ $\left(500 \times 25 \mu^{2}, 150 \times 3 \mu m^{2}\right)$ from the laboratory test vehicles. After the finished "lift-off" step test and device 
wafers were annealed in quartz tube in forming gas $\left(10 \% \mathrm{H}_{2}\right.$ in $\mathrm{N}_{2}$ ) atmosphere at different temperatures 200-420 ${ }^{\circ} \mathrm{C}$. The device wafers were finished by the standard double metal process with the highest temperature $350{ }^{\circ} \mathrm{C}$ during inter-metal dielectric deposition.

The properties of the AMR layers were analyzed on test samples by XRD analysis and magnetic measurements by a Lake Shore 7307 vibrating-sample magnetometer. On the same test wafers sheet resistance and surface roughness were measured after different annealing steps. The sheet resistance was measured by a 4-point probe and roughness by a laser scanning microscope.

The AMR measurements of the resistors were made in a measured magnetic field of permanent magnet or multipole magnetic tape with periodic magnetization as used for standard applications with $2 \lambda=4 \mathrm{~mm}$. The results on the tape were also compared to the results of single resistor from commercial AMR encoder bridge structure.

\section{RESULTS AND DISCUSSION}

The AMR effect is inversely proportional to the thickness, but unfortunately the coercivity $H_{\mathrm{c}}$ limits the lower thickness to about $50 \mathrm{~nm} .{ }^{1}$ The layer thickness $t$ can be calculated from the measured sheet resistance $R_{\mathrm{sh}}$ and the known resistivity $\rho, t=\rho / R_{\mathrm{sh}}$. Unfortunately, in thin films the resistivity depends on its thickness and structure as modeled by ${ }^{3}$. The accepted values are $123 \pm 30 \mathrm{n} \Omega \mathrm{m},{ }^{4}$ but H. Faltin ${ }^{5}$ observed even $196 \mathrm{n} \Omega \mathrm{m}$ for 120-nm-thick films deposited onto Si. Not at least, within the fixed geometry the resistivity of single resistor of about $1 \mathrm{k} \Omega$ is the optimum one. Therefore, an optimum $R_{\mathrm{sh}}$ is between $5 \Omega / \mathrm{sq}$ and $10 \Omega / \mathrm{sq}$.

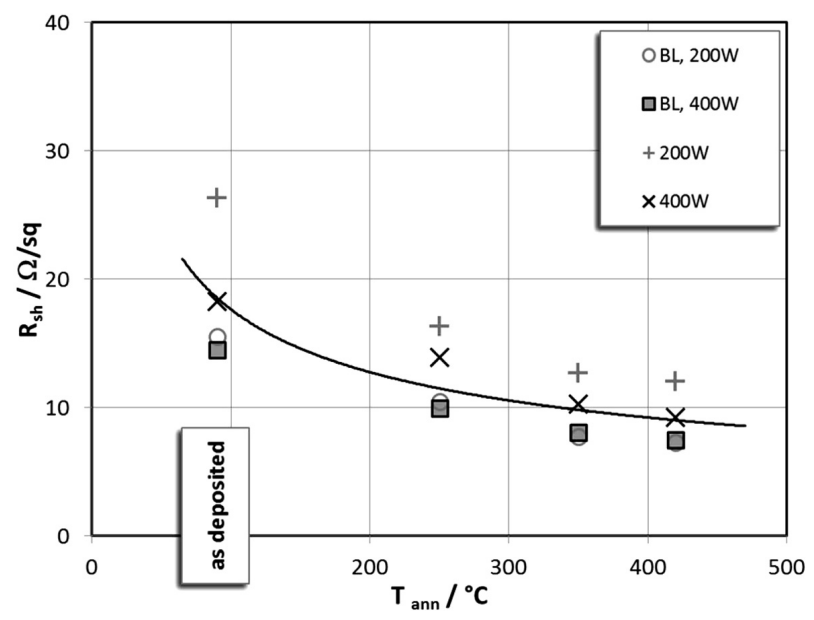

Figure 1: $R_{\mathrm{sh}}$ measured after the deposition and isochronal annealing in forming gas; crosses denote sheet resistances for films deposited without buffer layer

Slika 1: Plastna upornost $R_{\mathrm{pl}}$ po nanosu in izokronalnih popuščanjih v tvornem plinu; križi predstavljajo plastne upornosti filmov, nanesenih brez vmesne plasti
To characterize the AMR films their sheet resistance $R_{\text {sh }}$ was measured after different processing steps, and after isochronal (30 $\mathrm{min}$ ) annealing in forming gas. The results are shown in Figure 1. There is a rapid change in $R_{\text {sh }}$ for the samples deposited without a buffer layer. The layers deposited onto the buffer exhibit a moderate reduction in the resistivity up to the annealing at $350{ }^{\circ} \mathrm{C}$, which is also the highest temperature in the process. Generally speaking, samples without buffer, and samples deposited with lower power have a higher $R_{\text {sh }}$. Since the sputtering energy P.t was set to $17 \mathrm{~kJ}$ the difference is in the layer structure. The final $R_{\mathrm{sh}}$ was $8-12 \Omega / \mathrm{sq}$, close to our demands for an AMR sensor. Annealing at $400{ }^{\circ} \mathrm{C}$ and $420{ }^{\circ} \mathrm{C}$ does not significantly change the resistance, but microscopic investigations show unwanted changes in the structure of the film and an increase in the surface roughness $S_{\text {ra }}$ from $10-20 \mathrm{~nm}$ to over $50 \mathrm{~nm}$, especially for films deposited without a buffer.

The reduction of $R_{\mathrm{sh}}$ after annealing at $350{ }^{\circ} \mathrm{C}$ indicates strong changes in the crystal structure of the $\mathrm{Ni}-\mathrm{Fe}$ alloy layer. The XRD analysis in Figure 2 shows changes in the preferred (111) orientation after annealing up to $350{ }^{\circ} \mathrm{C}$. Annealing at higher temperatures has no effect on the orientation of the crystallites. In the XRD pattern a weak (200) Cr peak is also observed as well a strong (400) Si. Obviously our presumption for buffer layers does not work. In any case, the Cr buffer has some beneficial effects on the surface roughness and it significantly reduces the sheet resistivity of at least the annealed samples.

The magnetic properties of the deposited AMR layers are shown in next Figure 3. From rather rough plot we can see a distinctive difference between the plots for easy axis of magnetization (full circles), perpendicular orientation of magnetic field to the surface and hard axis (open circles), lying parallel to the surface. From this plot the coercivity $H_{c}$ is estimated to be $5 \mathrm{kA} / \mathrm{m}$. Since these are the very first experiments, the effects of pro-

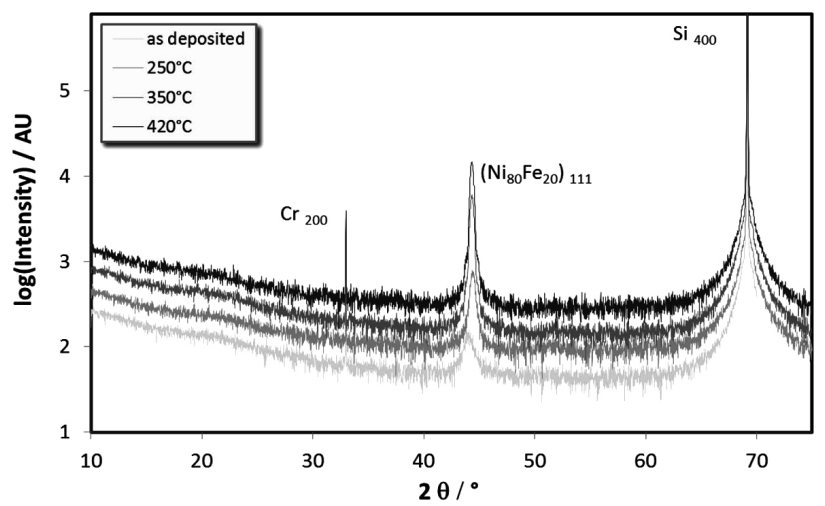

Figure 2: XRD pattern for a layer deposited onto buffer layer at 400 $\mathrm{W}$ and pressure $1.1 \mathrm{~Pa}$ after deposition and isochronal annealing at $(250,350$ and 420$){ }^{\circ} \mathrm{C}$

Slika 2: XRD-vzorec plasti, nanesene pri $400 \mathrm{~W}$ in tlaku $1.1 \mathrm{~Pa}$ na vmesno plast po nanosu in izokronalnih popuščanjih na $(250,350$ in 420) ${ }^{\circ} \mathrm{C}$ 
M. MAČEK, A. OBLAK: Ni-Fe ALLOY THIN FILMS FOR AMR SENSORS

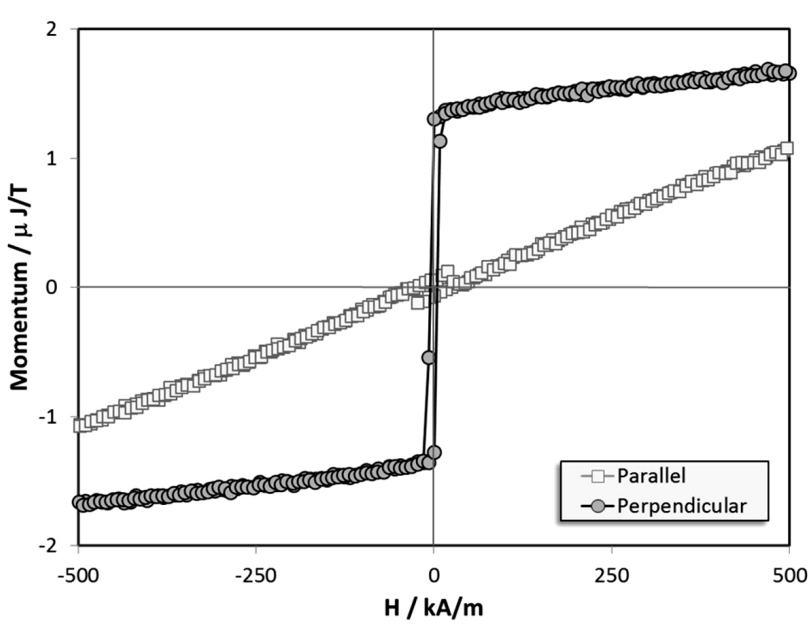

Figure 3: Magnetization curve for sample deposited with $400 \mathrm{~W}$ at 1.1 Pa, directly onto thermally grown $\mathrm{SiO}_{2}$ and annealed at $420{ }^{\circ} \mathrm{C}$ for $30 \mathrm{~min}$

Slika 3: Krivulja magnetizacije za vzorec nanesen pri $400 \mathrm{~W}$ in tlaku $1.1 \mathrm{~Pa}$, direktno na termičen $\mathrm{SiO}_{2}$ in popuščano 30 min na $420{ }^{\circ} \mathrm{C}$

cessing parameters on to magnetic properties and the structure revealed by XRD of soft ferromagnetic layers have not been studied yet.

The first experimental AMR resistors show promising results. In Figure 4 the responses $\Delta R / R_{\text {avg }}$ of the two test resistors $L x W=500 \times 25 \mu \mathrm{m}$ with slight differences in the processing (W\#10 without buffer, W\#08 with buffer layer) and a commercial AMR encoder are shown. The measurements were performed on a commercially available multipole magnetic tape with $2 \lambda=4 \mathrm{~mm}$ in steps of $0.1 \mathrm{~mm}$ and at a distance of $1.5 \mathrm{~mm}$ above the tape with a manual manipulator in all cases. From Figure 4 it is clear that there is no significant difference between both test samples, but their responses $(\sim 1.7 \%)$ are somewhat lower than that on the commercial $(\sim 1.9 \%)$ sensors.

\section{CONCLUSIONS}

The first AMR resistors were successfully fabricated by sputtering of $\mathrm{Ni}-\mathrm{Fe}$ alloy $\mathrm{Ni}_{80} \mathrm{Fe}_{20}$ in a Perkin Elmer apparatus and the necessary process steps for the subsequent annealing and fabrication of the resistors with predefined geometries with minimum dimensions $W=3 \mu \mathrm{m}$ were established.

The results from tests of the AMR resistors were comparable to the commercial one and encourages us to proceed with the development of extrapolators of custom design.

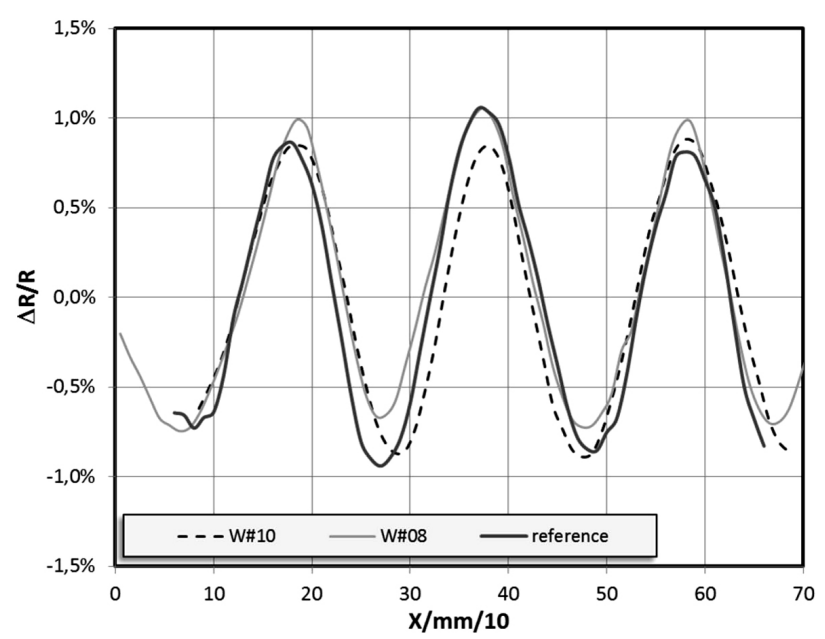

Figure 4: A typical response $\Delta R / R_{\text {avg }}$ of 2 test resistors and commercial reference to position over periodic multipole magnetic field with $2 \lambda=4 \mathrm{~mm}$ at a distance of $1.5 \mathrm{~mm}$

Slika 4: Tipična krivulja odziva $\Delta R / R_{\text {avg }} 2$ testnih uporov in komercialne reference na pomik nad periodično spreminjajočim magnetnim

\section{Acknowledment}

The authors acknowledge RLS company and especially director Mr. J. Novak and their employees Mrs. D. Domanjko and Mr. M. Janežič for support and encouraging during the first steps of AMR material process research and work on the design of the test encoder. Authors acknowledge dr. S. Gyergyek and dr. M. Spreitzer of the Jozef Stefan Institut, Ljubljana, for magnetic properties and XRD measurements.

\section{REFERENCES}

${ }^{1}$ A. V. Svalov, R. Aseguinolaza, A. Garcia-Arribas, I. Orue, J. M. Barandiaran, J. Alonso, M. L. Fernández-Gubieda, G. V. Kurlyandskaya, Structure and Magnetic Properties of Thin Ni-Fe alloy Films Near the Transcritical State, IEEE Trans Magn, 46 (2010) 2, 333-336

${ }^{2}$ W. Y. Lee, M. F. Toney, D. Mauri, P. Tameerug, E. Allen, High Magnetoresistance Permalloy Films Trough Growth on Seed layers of $\left(\mathrm{Ni}_{0.81} \mathrm{Fe}_{0.19}\right)_{1-\mathrm{x}} \mathrm{Cr}_{\mathrm{x}}$, IEEE Trans. Magn., 36 (2000) 1, 381-387

${ }^{3}$ P. Wismann, K. Muller, Surface Physics, Springer-Verlag, Berlin 1975

${ }^{4}$ A. C. Reilly, W. Park, R. Slater, B. Ouaglal, R. Loloee, W. P. Pratt Jr., J. Bass, Perpendicular Giant magnetoresistance of $\mathrm{Co}_{91} \mathrm{Fe}_{9} / \mathrm{Cu}$ Exchange-Biased Spin-Valves: A Further Test of the Unified Picture, JMMM, 195 (1999), L269-L274

${ }^{5}$ H. A. Faltin, The Magnetic and Electrical Properties of Ni-Fe alloyCarbon Thin Film Multilayers, thesis College of William and Mary, Virginia, USA 2000 